\title{
Hydration patterns and physiologic quality of common bean seeds
}

\section{Padrão de hidratação e qualidade fisiológica de sementes de feijão}

\author{
Natalia Carolina Moraes Ehrhardt-Brocardo ${ }^{1}$; Cileide Maria Medeiros Coelho ${ }^{2 *}$
}

\begin{abstract}
This study aimed to investigate the relationship between the hydration pattern of landrace bean genotypes and their physiological quality. The hydration curve of eight landrace (BAFs 07, 13, 23, 42, $44,50,55,81$ ) and two commercial cultivars (IPR-88-Uirapurú and Iapar 81) genotypes was determined from seed moisture. Determination of initial physiological quality was performed by germination and vigor tests (seedling performance and accelerated aging). Characterization of the genotypes, regarding accelerated aging tests, showed that BAFs $13,42,55$ and 81 had the highest physiological potential, whereas BAFs 07, 23, 44, 50 and the commercial cultivars had lower physiological quality. The hydration curve followed a triphasic pattern with radicle protrusion occurring between 21 and 27 hours after seed hydration. The percentage of reserves translocated to the seedling during formation showed that BAF 42 had the highest conversion efficiency compared to the smaller efficiencies of BAFs 23,50 and Iapar 81. The seedling length test showed that BAFs 42 and 55 had the most vigorous seedlings, which was driven by the high percentage of reserves translocated to the seedling during formation. BAFs 23, 50 and the cultivar Iapar 81 showed lower reserve translocation, demonstrating that low mobilization potential leads to smaller seedlings. The hydration of bean seeds during germination was affected by physiological quality, as genotypes considered more vigorous exhibited higher hydration rates than those of the less vigorous genotypes.
\end{abstract}

Key words: Phaseolus vulgaris. Germination. Vigor. Landrace genotypes.

\section{Resumo}

\begin{abstract}
O trabalho objetivou verificar relação do padrão de hidratação de genótipos crioulos de feijão e a sua qualidade fisiológica. Utilizaram-se oito genótipos crioulos (BAFs 07, 13, 23, 42, 44, 50, 55, 81) e dois comerciais (IPR-88-Uirapurú e Iapar 81) submetidos à determinação da curva de hidratação por meio da umidade das sementes. A determinação da qualidade fisiológica inicial foi realizada por meio do teste de germinação e testes de vigor (desempenho de plântulas e envelhecimento acelerado). A caracterização dos genótipos quanto ao teste de envelhecimento acelerado evidenciou os BAFs 13, 42, 55 e 81 como sendo de maior potencial fisiológico, e os BAFs 07, 23, 44 e 50 e cultivares comerciais, apresentando menor qualidade fisiológica. A curva de hidratação seguiu padrão trifásico com protrusão radicular entre 21 e 27 horas. O percentual de reserva translocada para a formação da plântula demonstrou que o BAF 42 obteve a maior eficiência de conversão comparada às menores, BAFs 23 e 50 e cultivar Iapar 81. Os BAFs 42 e 55 apresentaram plântula mais vigorosa pelo teste de comprimento de plântulas, decorrente do alto percentual de reserva translocada para a formação da plântula. Os BAFs 23 e 50 e a cultivar Iapar 81 apresentaram menor translocação de reservas e demonstraram que este baixo potencial de mobilização culminou com plântulas menores. A hidratação das sementes de feijão durante a germinação foi afetada pela qualidade fisiológica, uma vez que, os genótipos considerados mais vigorosos apresentaram maior velocidade de hidratação, comparados aos genótipos de menor vigor.
\end{abstract}

Palavras-chave: Phaseolus vulgaris. Germinação. Vigor. Genótipos crioulos.

\footnotetext{
${ }^{1}$ Bióloga, Discente de Doutorado, Programa de Pós-Graduação em Produção Vegetal, Universidade do Estado de Santa Catarina, UDESC, Lages, SC, Brasil. Bolsista CAPES. E-mail: biosapos@gmail.com

${ }^{2}$ Eng $^{\mathrm{a}} \mathrm{Agr}^{\mathrm{a}}$, Prof ${ }^{\mathrm{a}} \mathrm{Dr}^{\mathrm{a}}$ em Ciências, Departamento de Agronomia, UDESC, Lages, SC, Brasil. E-mail: cileide.souza@udesc.br; cileide.coelho@pq.cnpq.br

* Author for correspondence
} 


\section{Introduction}

Seed quality is defined as the sum of genetic, physical, health, and physiological attributes. Of these, physiological characteristics are particularly important since they relate to the ability of a seed to germinate, emerge, and quickly result in a normal seedling under a wide range of environmental conditions (TUNES et al., 2011). Several studies of seeds of landrace genotypes originating at the Bean Active Germplasm Bank (BAF) at the Santa Catarina State University have investigated morpho-agronomic (COELHO et al., 2007; COELHO et al., 2010b), molecular (CARVALHO et al., 2008), biochemical (PEREIRA et al., 2009), technological (COELHO et al., 2008; BORDIN et al., 2010), nutritional (PEREIRA et al., 2011) and physiological seed characteristics (COELHO et al., 2010a, 2012; MICHELS et al., 2014).

Characterization of the physiological potential of landrace bean genotype seeds based on the percentage of germination, vigor, and the intrinsic capacity of bean genotypes to behave differently, thus causing different responses among genotypes, allows assessment of the effect of genotype on seed vigor. Higher physiological potential of landrace seeds was observed in comparison to commercial cultivars. The former were favored by an extensive genetic basis and a relative ease of adaptation to the environmental conditions, whereas commercial cultivars were considered strains with limited genetic basis (COELHO et al., 2010a; MICHELS et al., 2014).

As such, genetic diversity is intrinsic to landrace genotypes. If the selection process by successive selfing promotes greater homogeneity and stability within the respective population, substantial diversity must occur between genotypes. Since the selection process in the field was conducted for eight seasons, it is possible to infer this behavior and conduct more detailed physiological studies, thus clarifying physiological differences between seeds with respect to genotypes.
Water is the most decisive factor in the process of germination, as it controls tissue rehydration and subsequent intensification of respiration and digestive and translocative metabolic activities required to supply energy and nutrients for the resumption of embryonic axis growth (ATAIIDE et al., 2014; KIKUCHI et al., 2006). The rate of water absorption is controlled by seed water content, water availability, environmental temperature, and rate of water absorption. The water absorption rate does not depend exclusively on the environment, because it depends on intrinsic characteristics of the genotype that are related to its physiological quality (VERTUCCI; LEOPOLD, 1983). Machado Neto et al. (2004) argued that when seeds are subjected to water stress, vigor is more affected than germination. Similarly, Braga et al. (1999) pointed out that the response of seeds germinated under water stress showed a dependence on genotype physiological quality. Thus, since the hydration behavior of bean seeds under water stress conditions is closely related to physiological quality, under balanced water conditions it is suggested that these genotypes also depend on their physiological potential. Therefore, analysis of the hydration process may provide insights into the specific physiological process occurring in the seeds, and thus, it is a tool to understand the physiological quality of different genotypes. This study aimed to investigate the relationship between the hydration pattern of landrace genotypes of beans throughout germination and physiological quality.

\section{Material and Methods}

This study was conducted using seeds of eight landrace bean genotypes (BAFs 07, 13, 23, 42, 44, $50,55,81)$ and two commercial cultivars (IPR88-Uirapurú and Iapar 81) originally from the Bean Active Germplasm Bank (BAF) of the Santa Catarina State University. Genotypes underwent successive selfing selection that favored greater homogeneity and stability within the population, 
having been previously characterized and studied in eight consecutive seasons.

Seeds were produced in a field experiment conducted in a randomized complete block design during the agricultural season of 2012/2013 by conventional farming in Campos Novos, Santa Catarina. Harvested seeds were stored in a dry chamber at $10^{\circ} \mathrm{C}$ and $50 \%$ relative humidity until analysis.

Determination of hydration pattern throughout the germination process of the different landrace bean genotypes and commercial cultivars was performed with recourse to the hydration curve developed through observation of changes in seed moisture content using the standard oven method at $105 \pm 3{ }^{\circ} \mathrm{C}$ for $24 \mathrm{~h}$ (BRASIL, 2009). Evaluation of physiological quality and characterization of seed vigor were performed by germination and vigor tests (seedling performance and accelerated aging).

\section{Standard curve of hydration}

Determination of the standard curve of hydration was performed at predetermined time intervals (every 3 h) until at least $50 \%$ of seeds in each replication presented radicle protrusion. Four replications of 50 seeds each were assayed on Germitest paper towels moistened with distilled water at a ratio of 2,5 $\mathrm{mL} . \mathrm{g}^{-1}$ dry paper. Seeds remained in the dark in a Mangelsdorf type germinator in the vertical position at a constant temperature of $25^{\circ} \mathrm{C}$, according to the criteria of the Rules for Seed Analysis (BRASIL, 2009). At each time point, seed water content was measured by taking as a reference the standard oven method at $105 \pm 3^{\circ} \mathrm{C}$ for $24 \mathrm{~h}$ (BRASIL, 2009). Regression analysis was performed with the objective of finding a regression equation for each genotype where the coefficient of determination showed the most significant fit to the germination pattern. A $3^{\text {rd }}$ degree equation showed best fit for all genotypes, which corresponded to the triphasic pattern of hydration during germination (BEWLEY; BLACK, 1978). In order to monitor a possible influence of storage time on hydration pattern, the standard curve of hydration was determined in December 2014 and reviewed in February 2015.

\section{Seedling performance test}

Determination of seedling length was performed at various hydration time points $(48,72,96$, and 120 h). Four replications were assembled with 10 seeds each on Germitest type paper towels with a line drawn longitudinally in the upper third of the paper and moistened with distilled water at a ratio of $2,5 \mathrm{~mL} \cdot \mathrm{g}^{-1}$ dry paper. Seeds remained in the dark in a Mangelsdorf type germinator at a constant temperature of $25^{\circ} \mathrm{C}$, according to the criteria of the Rules for Seed Analysis (BRASIL, 2009). After evaluation of the total seedling length, results were expressed as mean seedling length (mm) (NAKAGAWA, 1999). Seedlings and cotyledons corresponding to $120 \mathrm{~h}$ of hydration were then separated, contained in paper bags, and dried in a forced air circulation stove at $60^{\circ} \mathrm{C}$ for $48 \mathrm{~h}$. Samples were then removed from the stove, placed in a desiccator, and weighed, in order to determine total dry mass of replicated seedlings and cotyledons. Results were expressed as mg.seedling ${ }^{-1}$ and mg.cotyledon ${ }^{-1}$ (NAKAGAWA, 1999). The percentage of reserves translocated to seedling formation was measured by calculating the difference between the remaining dry mass in the cotyledons and the dry mass translocated to the seedling relative to the dry mass of the seed.

\section{Germination test}

Germination tests were conducted on Germitest type paper towel moistened with distilled water at a ratio of $2,5 \mathrm{~mL} . \mathrm{g}^{-1}$ dry paper with four replications of 50 seeds each. Seeds remained in a Mangelsdorf type germinator in the vertical position at a constant temperature of $25^{\circ} \mathrm{C}$, according to the criteria of the Rules for Seed Analysis (BRASIL, 2009). The percentage of germinated seeds (normal seedlings) was evaluated 5 days after test initiation. 


\section{Accelerated aging test}

Polystyrene crystal boxes $\left(\mathrm{Gerbox}^{\circledR}\right)(11 \mathrm{~cm} \mathrm{x}$ $11 \mathrm{~cm} \times 3 \mathrm{~cm}$ ) with aluminum screens suspended inside were used such that sample seeds were distributed in a single layer on the surface of the screen. After obtaining the samples, $40 \mathrm{~mL}$ distilled water was added to the bottom of the boxes to ensure a relative humidity level of the air close to $100 \%$ (saturated atmosphere). Boxes were closed and placed in an aging chamber for $72 \mathrm{~h}$ at $42^{\circ} \mathrm{C}$ (MARCOS FILHO, 1999). In order to monitor the procedures used in the test, a control was also installed for each genotype to assess seed water content using the standard oven method at a temperature of $105 \pm 3^{\circ} \mathrm{C}$ for $24 \mathrm{~h}$ (BRASIL, 2009). Germination was conducted on Germitest type paper towel moistened with distilled water at a ratio of 2,5 mL. $\mathrm{g}^{-1}$ dry paper with four replications of 50 seeds each. Seeds remained in a Mangelsdorf type germinator in the vertical position at a constant temperature of $25^{\circ} \mathrm{C}$, according to the criteria of the Rules for Seed Analysis (BRASIL, 2009). The percentage of vigor (normal seedlings) was evaluated 5 days after test initiation.

\section{Statistical analysis}

The adopted experimental design was a completely randomized approach and analysis of variance ( $F$ test) was performed. Averages were grouped by the Scott-Knott test at 5\% probability using Assistat software (SILVA; AZEVEDO, 2002). In addition, regression analysis was performed in order to characterize water absorption and seedling length of the different genotypes at various hydration time points.

\section{Results and Discussion}

\section{Standard curve of hydration}

Through the assessment of water content of dry seeds subjected to different periods of hydration, it was observed that landrace and commercial genotypes of beans fit a triphasic model of hydration (BEWLEY; BLACK, 1978). Furthermore, it was determined that phase II ended 21-27 $\mathrm{h}$ after hydration (Figures 1A and B) resulting in radicle protrusion.

The behavior of the hydration curve allowed differentiation of genotypes by water absorption rate. Genotypes BAFs 7, 44 and the commercial cultivar Iapar 81 had lower hydration rates than those of other genotypes. The diversity of rates at which seeds of these genotypes absorbed water had already been observed in technological quality assessment where the genotypes BAFs 7 and 44 had the longest time requirements for maximum hydration (BORDIN et al., 2010). Thus, the difference in hydration behavior among genotypes may be related to the physiological quality of the seeds. For example, previous research in soybeans indicated that seeds with higher physiological quality hydrate more slowly (ROCHA et al., 1984; ROSSETTO et al., 1995; BECKERT; SILVA, 2002). After establishing the hydration curve, viability and vigor tests were performed in order to determine the relationship between the pattern of hydration and the physiological quality of the seeds.

\section{Seedling performance test}

The genotypes showed no statistical differences regarding seedling accumulation of dry matter after hydration for $120 \mathrm{~h}$ (Table 1), the same time point as when first germination counts were completed (BRASIL, 2009). However, BAF 42 had the highest conversion efficiency $(40,11 \%)$ of percentage of reserves translocated to the formation of seedling, as compared to BAF $23(21,45 \%)$ and $50(24,97 \%)$, and commercial cultivar Iapar 81 (23,07\%). 
Figure 1. Hydration patterns of landrace and commercial bean genotypes (RP: radicle protrusion).

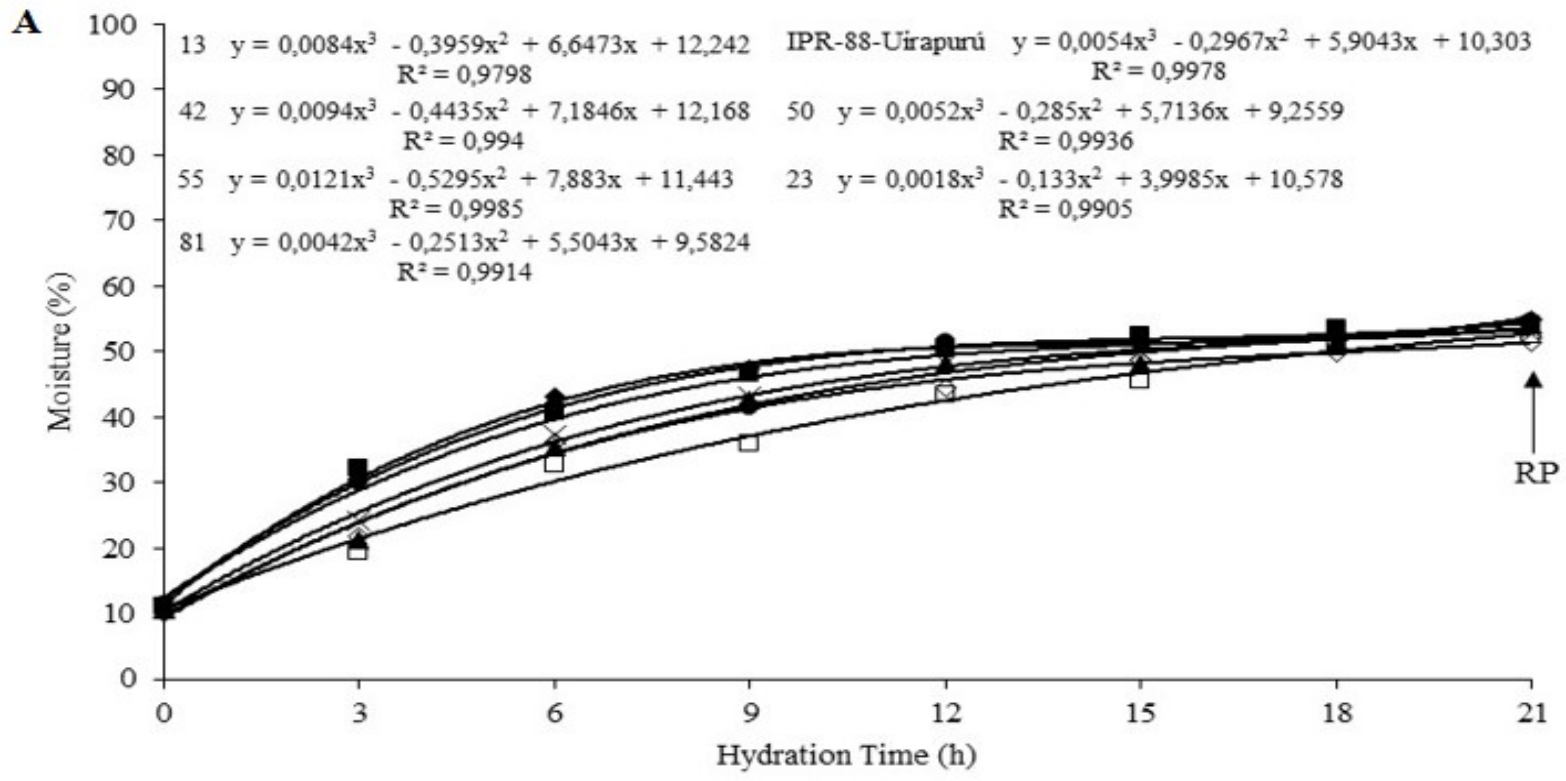

• 13 - $42 \bullet 55 \Delta 81 \quad \square 23 \diamond 50 \times$ IPR-88-Uirapurú

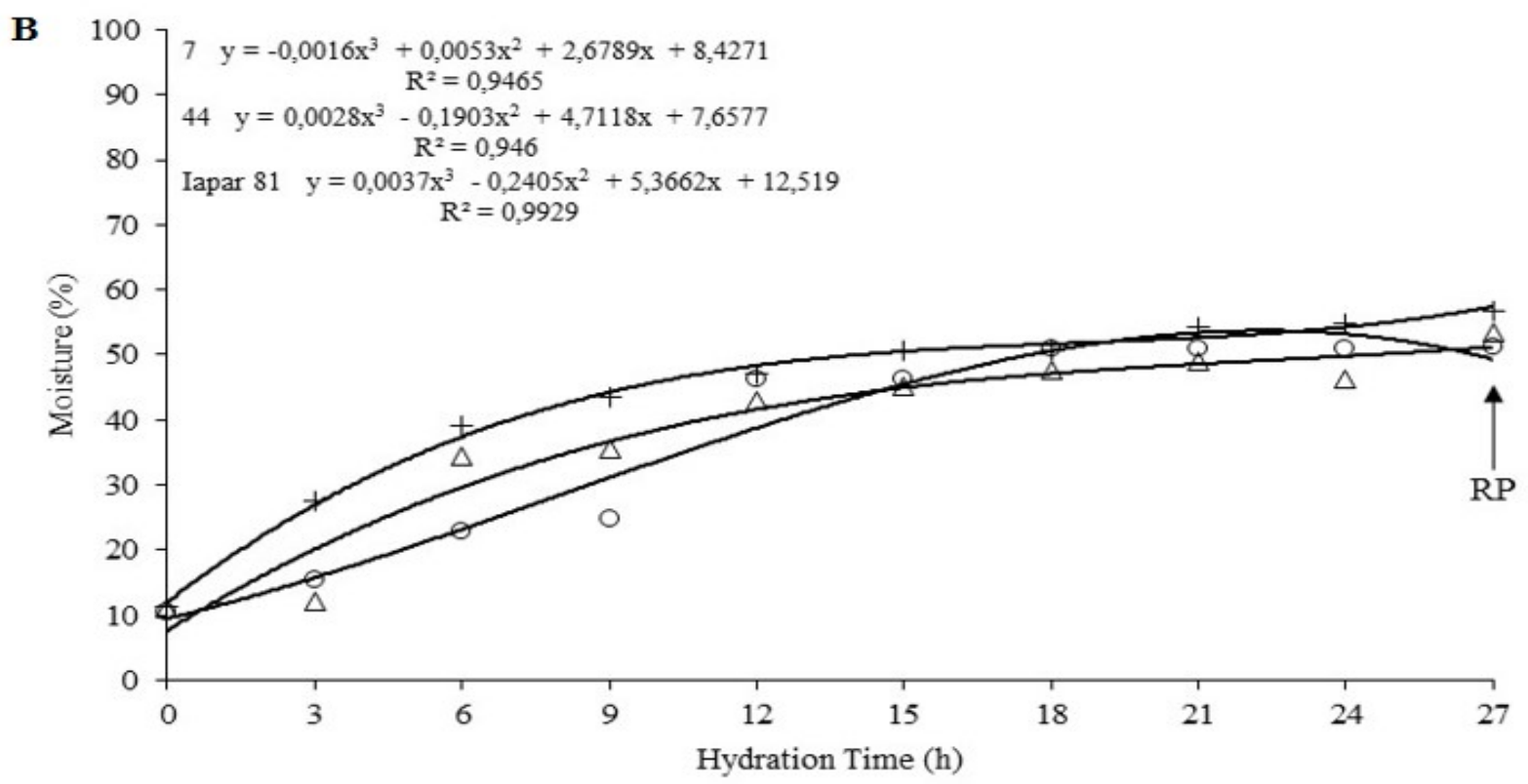

○ 744 +Iapar 81 
Table 1. Dry mass and percentage of reserve mobilization of been seedling genotypes after hydration for $120 \mathrm{~h}$.

\begin{tabular}{ccc}
\hline Genotype & Dry Mass of Seedling (mg) & Mobilization to Seedling (\%) \\
\hline BAF 07 & $55,10 \mathrm{a}$ & $32,72 \mathrm{a}$ \\
BAF 13 & $65,63 \mathrm{a}$ & $30,19 \mathrm{a}$ \\
BAF 23 & $78,02 \mathrm{a}$ & $21,45 \mathrm{~b}$ \\
BAF 42 & $73,97 \mathrm{a}$ & $40,11 \mathrm{a}$ \\
BAF 44 & $65,92 \mathrm{a}$ & $28,75 \mathrm{a}$ \\
BAF 50 & $56,91 \mathrm{a}$ & $24,97 \mathrm{~b}$ \\
BAF 55 & $76,31 \mathrm{a}$ & $34,82 \mathrm{a}$ \\
BAF 81 & $68,36 \mathrm{a}$ & $33,81 \mathrm{a}$ \\
IPR-88-Uirapurú & $76,57 \mathrm{a}$ & $30,76 \mathrm{a}$ \\
Iapar 81 & $57,77 \mathrm{a}$ & $23,07 \mathrm{~b}$ \\
\hline CV (\%) & 16,02 & 16,27 \\
\hline
\end{tabular}

Mean values followed by the same letter do not differ according to the Scott-Knott test (5\%).

Analysis of seedling length results at different hydration time points (Figure 2) showed that BAFs 42 and 55 were the most vigorous seedling genotypes, thus demonstrating the potential of these genotypes to convert stored reserves into seedling structures. Similarly, characterization of physiological potential of seeds of these genotypes was estimated by the evaluation of root length after hydration for $120 \mathrm{~h}$. Of all assayed genotypes, BAF 55 had the longest root length (COELHO et al., 2010a).

Figure 2. Length of various bean genotype seedlings at different hydration time points.

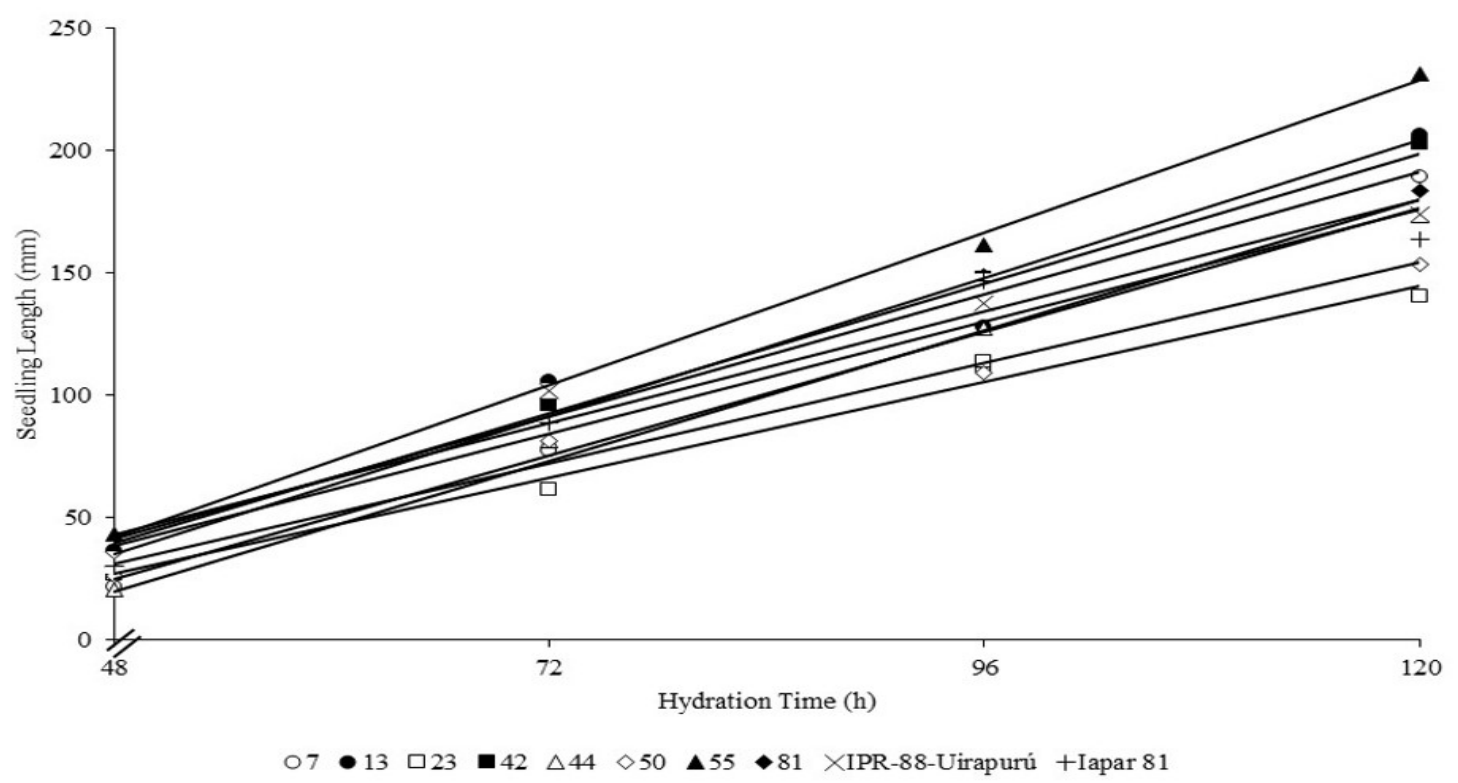

Equations obtained by regression analysis: $\hat{y}(23)=2.228 x-87.382 \mathrm{R}^{2}=0.974 * * ; \hat{\mathrm{y}}(50)=26.346 \mathrm{x}-653.950 \mathrm{R}^{2}=0.999 * * ; \hat{\mathrm{y}}(13)$ $=1.633 \mathrm{x}-51.475 \mathrm{R}^{2}=0.986^{* *} ; \hat{\mathrm{y}}(42)=2.343 \mathrm{x}-76.810 \mathrm{R}^{2}=0.998^{* *} ; \hat{\mathrm{y}}(55)=2.107 \mathrm{x}-76.252 \mathrm{R}^{2}=0.995 * * ; \hat{\mathrm{y}}(81)=1.709 \mathrm{x}-$ $50.942 \mathrm{R}^{2}=0.985^{* *} ; \hat{\mathrm{y}}(\mathrm{IPR}-88$-Uirapurú $)=2.589 \mathrm{x}-82.080 \mathrm{R}^{2}=0.998 * * \hat{\mathrm{y}}(7)=4.352 \mathrm{x}-144.850 \mathrm{R}^{2}=0.999 * * ; \hat{\mathrm{y}}(44)=1.905 \mathrm{x}$ $-48.300 \mathrm{R}^{2}=0.971 * * ; \hat{\mathrm{y}}($ Iapar 81$)=4.947 \mathrm{x}-167.527 \mathrm{R}^{2}=0.992 *$.

$*$ or ** significant splitting by the $F$ test, where $*-5 \%$ significance and $* *-1 \%$ significance; $\mathrm{R}^{2}=$ determination coefficient of each significant equation. 
It was observed that the percentage of reserves translocated to seedling formation induced changes among the genotypes in the phenotypic characteristic of seedling length. BAFs 23, 50 and the commercial cultivar Iapar 81, which had the lowest translocation reserves, showed that low mobilization potential resulted in smaller seedlings, especially at the final time point (120 h) (Figure 2). A similar result was reported by Dan et al. (1987), who studied the transfer of dry matter as a method for assessing soybean seed vigor, and who showed that seedlings from better quality seeds had a greater reserve supply capacity, enhanced transformation of storage tissues, and better incorporation into the embryonic axis. Dutra and Teófilo (2007) argued that seeds qualified as potentially vigorous could sustain higher growth rates in the initial period of plant development. Initial early growth allows for improved and more rapid closure of the soil leading to decreased evaporation, more efficient water use, and increased competitive capacity, thus improving weed control (HENNING et al., 2010).

\section{Germination test and accelerated aging test}

From genotype germination percentage data (Table 2), it was observed that the genotypes with higher viability in germination test were BAFs
$81,55,13$ and the commercial cultivars IPR-88Uirapurú and Iapar 81.

The high germination percentage of BAFs 7 and 44 demonstrates the importance of the physiological potential of these landrace genotypes (COELHO et al., 2010a), as both had higher germination percentages than the minimum required by the seed beans marketing standards (80\%) (BRASIL, 2005).

After determining seed vigor differences (Table 2), stress imposed by the accelerated aging test allowed differentiation between bean genotypes. Genotypes BAFs 13, 81, 42 and 55 had the highest physiological quality, whereas BAFs $07,23,44,50$ and the cultivars IPR-88-Uirapurú and Iapar $81 \mathrm{had}$ the lowest physiological quality.

Through the vigor tests performed, it was found that in the evaluation of the percentage of reserve mobilization for seedling and seedling length, the genotypes with greatest potential of conversion of stored reserves in seedling structures (BAFs 42 and 55) belonged to the group of high vigor genotypes determined by the accelerated aging test, thus demonstrating high physiological potential. Previous studies also confirmed that genotype BAF 55 was superior with respect to the physiological quality of the seed (COELHO et al., 2010a, 2010b, 2012).

Table 2. Germination and vigor percentage as measured by the accelerated aging test of various bean seed genotypes.

\begin{tabular}{ccc}
\hline Genotype & Germination (\%) & Accelerated Aging (\%) \\
\hline BAF 07 & $79 \mathrm{~b}$ & $75 \mathrm{~b}$ \\
BAF 13 & $91 \mathrm{a}$ & $88 \mathrm{a}$ \\
BAF 23 & $85 \mathrm{~b}$ & $79 \mathrm{~b}$ \\
BAF 42 & $85 \mathrm{~b}$ & $83 \mathrm{a}$ \\
BAF 44 & $77 \mathrm{~b}$ & $59 \mathrm{~b}$ \\
BAF 50 & $83 \mathrm{~b}$ & $78 \mathrm{~b}$ \\
BAF 55 & $93 \mathrm{a}$ & $83 \mathrm{a}$ \\
BAF 81 & $94 \mathrm{a}$ & $87 \mathrm{a}$ \\
IPR-88-Uirapurú & $91 \mathrm{a}$ & $75 \mathrm{~b}$ \\
Iapar 81 & $90 \mathrm{a}$ & $73 \mathrm{~b}$ \\
\hline CV (\%) & 4,86 & 9,15 \\
\hline
\end{tabular}

Mean values followed by the same letter do not differ according to the Scott-Knott test (5\%). 
By relating the hydration pattern and physiological quality of the various genotypes, it was observed through the characterization of seed vigor, that the less vigorous genotypes required more time for repairing the membrane system during the initial hydration process. Similarly, Bortolotto et al. (2008), in work with irrigated rice, seeds with lower physiological quality presented a lower hydration rate compared to higher quality seeds.

This lower rate is associated with the understanding that seeds with lower vigor promote the repair and/or protection of the membrane system during the initial stage of hydration, before initiating growth of the embryonic axis. The time consumed by this process thus increases the total time before germination (COSTA et al., 2008). Thus, the tested genotypes demonstrated a pattern of hydration behavior that was very similar to that observed in the vigor characterization tests.

\section{Conclusion}

The pattern of hydration of bean seeds showed a positive relationship with observed physiological quality among genotypes. The most vigorous had higher hydration rates than those of genotypes with lower vigor. Analysis of hydration behavior can provide insight into which physiological process is occurring in the seed, thus providing a tool to understand the physiological quality of different genotypes.

\section{Acknowledgments}

To CNPq (Conselho Nacional de Desenvolvimento Científico e Tecnológico; National Counsel of Technological and Scientific Development), for the financial support granted to project 4818212011-6 and FAPESC - CP 04/2014 2015 TR 649 (Fundação de Amparo a Pesquisa e Inovação do Estado de Santa Catarina) and CNPq by productivity grant for second author.

\section{References}

ATAÍDE, G. M.; BORGES, E. E. L.; FLORES, A. V.; CASTRO, R. V. O. Avaliação preliminar da embebição de sementes de jacarandá-da-bahia. Pesquisa Florestal Brasileira, Colombo, v. 34, n. 78, p. 133-139, 2014.

BECKERT, O. P.; SILVA, W. R. da. O uso da hidratação para estimar o desempenho de sementes de soja. Bragantia, Campinas, v. 61, n. 1, p. 61-69, 2002.

BEWLEY, J. D.; BLACK, M. Physiology and biochemistry of seeds in relation to germination. Berlin: Springer Verlag, 1978. 306 p.

BORDIN, L. C.; COELHO, C. M. M.; SOUZA, C. A. de; ZILIO, M. Diversidade genética para a padronização do tempo e percentual de hidratação preliminar ao teste de cocção de grãos de feijão. Ciência e Tecnologia de Alimentos, Campinas, v. 30, n. 4, p. 890-896, 2010.

BORTOLOTTO, R. P.; MENEZES, N. L. de; GARCIA, D. C.; MATTIONI, N. M. Comportamento de hidratação e qualidade fisiológica das sementes de arroz. Bragantia, Campinas, v. 67, n. 4, p. 991-996, 2008.

BRAGA, L. F.; SOUSA, M. P.; BRAGA, J. F.; SÁ, M. E. de. Efeito da disponibilidade hídrica do substrato na qualidade fisiológica de sementes de feijão. Revista Brasileira de Sementes, Brasília, v. 21, n. 2, p. 95-102, 1999.

BRASIL. Ministério da Agricultura, Pecuária e Abastecimento. Instrução Normativa 25/2005, de 16 de dezembro de 2005, Ministério da Agricultura, Pecuária e do Abastecimento (Anexo V - Padrões para produção e comercialização de sementes de feijão). SNAD/DNDN/ CLAV: Diário Oficial [da] União, Brasília, 20 dez. 2005, Seção 1, p. 18.

Brasília: $\overline{\text { MAPA}} / \mathrm{ACS}, 2009.395 \mathrm{p}$.

Regras para análise de sementes (RAS).

CARVALHO, M. F.; CRESTANI, M.; FARIAS, F. L.; COIMBRA, J. L. M.; BOGO, A.; GUIDOLIN, A. F. Caracterização da diversidade genética entre acessos crioulos de feijão (Phaseolus vulgaris L.) coletados em Santa Catarina por marcadores RAPD. Ciência Rural, Santa Maria, v. 38, n. 6, p. 1522-1528, 2008.

COELHO, C. M. M.; COIMBRA, J. L. M.; SOUZA, C. A. de; BOGO, A.; GUIDOLIN, A. F. Diversidade genética em acessos de feijão (Phaseolus vulgaris L.). Ciência Rural, Santa Maria, v. 37, n. 5, p. 1241-1247, 2007. 
COELHO, C. M. M.; MOTA, M. R.; SOUZA, C. A. de; MIQUELLUTI, D. J. Potencial fisiológico em sementes de cultivares de feijão crioulo (Phaseolus vulgaris L.). Revista Brasileira de Sementes, Brasília, v. 32, n. 3 p. 97-105, 2010a.

COELHO, C. M. M.; SOUZA, C. A. de; DANELLI, A. L. D.; PEREIRA, T.; SANTOS, J. C. P.; PIAZZOLI, D. Capacidade de cocção de grãos de feijão em função do genótipo e da temperatura da água de hidratação. Ciência e Agrotecnologia, Lavras, v. 32, n. 4, p. 1080-1086, 2008.

COELhO, C. M. M.; SOUZA, C. A. de; ZILIO, M.; MICHELS, A. F. Ação de dessecante na pré-colheita sobre a produtividade e a qualidade fisiológica de sementes crioulas de feijoeiro. Semina: Ciências Agrárias, Londrina, v. 33, n. 1, p. 2973-2980, 2012.

COELHO, C. M. M.; ZILIO, M.; SOUZA, C. A. de; GUIDOLIN, A. F.; MIQUELLUTI, D. J. Características morfo-agronômicas de cultivares crioulas de feijãocomum em dois anos de cultivo. Semina: Ciências Agrárias, Londrina, v. 31, n. 1, p. 1177-1186, 2010b.

COSTA, C. J.; VILLELA, F. A.; BERTONCELLO, M. R. Pré-hidratação de sementes de ervilha e sua interferência na avaliação do potencial fisiológico. Revista Brasileira de Sementes, Brasília, v. 30, n. 1, p. 198-207, 2008.

DAN, E. L.; MELLO, V. D. C.; WETZEL, C. T.; POPINIGIS, F.; ZONTA, É. P. Transferência de matéria seca como método de avaliação do vigor de sementes de soja. Revista Brasileira de Sementes, Brasília, v. 9, n. 3, p. 45-55, 1987.

DUTRA, A. S.; TEÓFILO, E. M. Envelhecimento acelerado para avaliar o vigor de sementes de feijão caupi. Revista Brasileira de Sementes, Brasília, v. 29, n. 1, p. 193-197, 2007.

HENNING, F. A.; MERTZ, L. M.; JACOB JUNIOR, E. A.; MACHADO, R. D.; FISS, G.; ZIMMER, P. D. Composição química e mobilização de reservas em sementes de soja de alto e baixo vigor. Bragantia, Campinas, v. 69, n. 3, p. 727-734, 2010.

KIKUCHI, K.; KOIZUMI, M.; ISHIDA, N.; KANO, H. Water uptake by dry beans observed by micro-magnetic resonance imaging. Annals of Botany, London, v. 98, n. 3, p. 545-553, 2006.

MACHADO NETO, N. B.; SATURNINO, S. M.; BOMFIM, D. C.; CUSTÓDIO, C. C. Hydric stress induced by mannitol and sodium chloride in soybean cultivars. Brazilian Archives of Biology and Technology, Curitiba, v. 47, n. 4, p. 521-529, 2004.
MARCOS FILHO, J. Teste de envelhecimento acelerado. In: KRZYZANOWSKI, F. C.; VIEIRA, R. D.; FRANÇA NETO, J. B. (Ed.). Vigor de sementes: conceitos e testes. Londrina: ABRATES, 1999. cap. 3, p. 1-24.

MICHELS, A. F.; SOUZA, C. A. de; COELHO, C. M. M.; ZILIO, M. Qualidade fisiológica de sementes de feijão crioulo produzidas no oeste e planalto catarinense. Revista Ciência Agronomica, Fortaleza, v. 45, n. 3, p. 620-632, 2014.

NAKAGAWA, J. Testes de vigor baseados no desempenho das plântulas. In: KRZYZANOWSKI, F. C.; VIEIRA, R. D.; FRANÇA NETO, J. B. (Ed.). Vigor de sementes: conceitos e testes. Londrina: ABRATES, 1999. cap. 2, p. 1-24.

PEREIRA, T.; COELHO, C. M. M.; BOGO, A.; GUIDOLIN, A. F.; MIQUELLUTI, D. J. Diversity in common bean landraces from South-Brazil. Acta Botanica Croatica, Zagreb, v. 68, n. 1, p. 79-92, 2009.

PEREIRA, T.; COELHO, C. M. M.; SANTOS, J. C. P.; BOGO, A.; MIQUELLUTI, D. J. Diversidade no teor de nutrientes em grãos de feijão crioulo no Estado de Santa Catarina. Acta Scientiarum Agronomy, Maringá, v. 33, n. 3, p. 477-485, 2011.

ROCHA, V. S.; SEDIYAMA, T.; SILVA, R. F.; SEDIYAMA, C. S.; THIEBAUT, J. T. L. Embebição de água e qualidade fisiológica de sementes de soja. Revista Brasileira de Sementes, Brasília, v. 6, n. 2, p. 51-66, 1984.

ROSSETTO, C. A. V.; FERNANDEZ, E. M.; MARCOS FILHO, J. Metodologia de ajuste do grau de umidade e comportamento das sementes de soja no teste de germinação. Revista Brasileira de Sementes, Brasília, v. 17, n. 2, p. 171-178, 1995.

SILVA, F. de A. S.; AZEVEDO, C. A. V. de. Versão do programa computacional Assistat para o sistema operacional Windows. Revista Brasileira de Produtos Agroindustriais, Campina Grande, v. 4, n. 1, p. 71-78, 2002.

TUNES, L. M.; PEDROSO, D. C.; BADINELLI, P. G.; TAVARES, L. C.; RUFINO, C. A.; BARROS, A. C. S. A.; MUNIZ, M. F. B. Envelhecimento acelerado em sementes de azevém com e sem solução salina e saturada. Ciência Rural, Santa Maria, v. 41, n. 1, p. 33-37, 2011.

VERTUCCI, C. W.; LEOPOLD, A. C. Dynamics of imbibition by soybean embryos. Plant Physiology, Glasgow, v. 72, n. 1, p. 190-193, 1983. 
